\title{
Construction of Middle School Students (SMA) Against Political Education (Phenomenology Study of State High School 3 Malang Students)
}

\author{
Basuki Agus Priyana Putra \\ Email : basukismanti@gmail.com \\ State High School 3 Malang
}

Article Info :

\section{Article history : \\ Received : September 5, 2019 \\ Revised : October 1, 2019 \\ Accepted : October 29, 2019 \\ ISSN 2620-8091, Online 2620-3812}

\begin{abstract}
This study aims to describe and understand the construction of high school students in political education, using a phenomenological approach. In theory, research is conducted to find propositions related to political education. This study uses a qualitative model located at SMAN 3 Malang with research subjects as the Chairperson of Intra-School Student Organizations (OSIS) and Class Representative Chair (PK). As informants are Citizenship Education teachers and parents of research subjects. This study shows the construction of high school students on political education in the form of concepts, implementation, objects, and benefits, following the five intelligence operations of Piaget's theory of constructivism such as external, reflective, incomplete circumstances, groping, and assimilation. Furthermore, the construction of high school students towards political education applies dialectics between individuals (high school students), society (student organizations), and knowledge (political education) which takes place in the order of moments of externalization, objectivation, and internalization, while 'outputs' follow moments of socialization and resocialization to stock of knowledge.
\end{abstract}

Keywords: Political Education, political participation, high school, student council

\section{ABSTRAK}

Penelitian ini bertujuan untuk mendeskripsikan dan memahami konstruksi siswa SMA terhadap pendidikan politik dengan menggunakan pendekatan fenomenologis. Secara teori, penelitian dilakukan untuk menemukan proposisi terkait dengan pendidikan politik. Penelitian ini menggunakan model kualitatif berlokasi di SMAN 3 Malang dengan subjek penelitian Ketua Organisasi Siswa Intra Sekolah (OSIS) dan Ketua Perwakilan Kelas (PK). Sebagai informan adalah guru Pendidikan Kewarganegaraan dan orang tua subjek penelitian. Penelitian ini menunjukan konstruksi siswa SMA terhadap pendidikan politik berupa konsep, implementasi, objek, dan manfaat, mengikuti lima operasi kecerdasan teori konstruktivisme Piaget seperti tekanan lingkungan eksternal, reflektif, keadaan tidak lengkap, groping, dan asimilasi. Selanjutnya, konstruksi siswa SMA terhadap pendidikan politik menerapkan dialektika antara individu (siswa SMA), masyarakat (organisasi siswa), dan pengetahuan (pendidikan politik) yang berlangsung dalam urutan momen eksternalisasi, objektivasi, dan internalisasi, sedangkan 'keluaran' mengikuti momen sosialisasi dan resosialisasi hingga stock of knowledge.

Please Cite This Articel As : Basuki agus priyana, Construction of Middle School Students (SMA) Against Political Education (Phenomenology Study of State High School 3 Malang Students): Journal of Local Government Issues (LOGOS), https://doi.org/10.22219/LOGOS.Vol2.No2.225-243 


\section{INTRODUCTION}

In the last few years, especially in Malang City, an interesting phenomenon has emerged related to relations between high school students, schools, parents of students, and the government. If observed, the relationship between students and schools raises the tendency of students to be more 'comfortable' at school or more and more students spend more time at school. Several reasons accompany this phenomenon, such as doing assignments, participating in extracurricular activities, preparing for competitions, taking part in IntraSchool Student Organizations (OSIS) and Class Representatives (PK), as well as various other activities. The point is they are associating, deliberating, negotiating, to set a vision and goals to be achieved together.

The second relation, which is between students and parents of students. The majority of parents aggressively encourage their children to engage in physical and organizational activities, even 'politics' in the scope of schools in interest organizations and leader cadre organizations such as OSIS and PK. However, on the other hand, there is a reluctance of students and parents to talk politics in a broader scope, as in the context of state administration. Students call themselves fond of organizing to the level of managing and leading but do not want to be called political.

The third relation, namely between students and the government. The government has a political interest in preparing students to become full citizens, including in political affairs. In collaboration with several institutions related to the political process such as political parties, the General Election Commission (KPU), and the Election Oversight Body (Bawaslu), the government is very active in disseminating political processes to students as beginner voters. This can be interpreted that the government wants students to have a view, especially in the political field, as the view desired by the government.

The phenomenon of high school students' interest in organizing has led to a form of passion. The term hobby is not quite right because, at this level, they are swamped and intensively involved in organizations, starting from the community of similar interests, to ideology-based communities. They follow a variety of organizations so that sometimes they take up a lot of formal learning time that they should have taken. If their formal study time is between 45-53 lesson hours in one week, then the involvement those in the organization reach 20-25 hours of study. It can be imagined how busy the students are in organizing.

Students' interest in organizing is channelled into various platforms. In the most straightforward category, there are standard student organizations, namely Intra-School Student Organizations (OSIS) and Class Representatives (PK). Students often refer to the student council as an executive body and the executive board of PK as a legislative body. Almost all organizations that students participate in have oral and written provisions. Written provisions in the form of the Articles of Association and by-laws. In it explained the main things such as the name of the organization, position, goals, membership, organizational structure, management, management election mechanism, management tenure, distribution of authority, performance

Please Cite This Articel As : Basuki agus priyana, Construction of Middle School Students (SMA) Against Political Education (Phenomenology Study of State High School 3 Malang Students): Journal of Local Government Issues (LOGOS), https://doi.org/10.22219/LOGOS.Vol2.No2.225-243 
accountability, and so on. In essence, the document contains a mechanism of political education because in it discussed the relationship of audiences with their representatives, the mechanism of achieving power, forms of power, distribution of power, ethics, and so on.

Like high schools in general, students of SMA Negeri 3 Malang also have political education organizations in the form of OSIS and PK. This organization is supported by a variety of activities that are accommodated in extracurricular activities. Each board of the extracurricular organization as well as the management of the OSIS and PK always follows the leadership replacement mechanism like a political process in a country. The political process begins with the formation of an election committee. Then the program preparation and election stages are carried out, for example, the selection of candidates, the socialization of candidates, the campaign of prospective leaders, voting, vote counting, determination of winners, preparation of administrators, the appointment of elected leaders, preparation of work programs, implementation, evaluation, and accountability reports. This is the original form of political education that takes place in schools.

Other facts were discovered during the election of the student council of Malang State High School 3 Malang for the past three years. This fact occurred at the stage of preparation for the election, at the time of the vote, and the stage of publication of results. In the preparation stage, the committee began by selecting ten candidates. Furthermore, three selected student council candidates are allowed to form their respective success teams. The activities of each successful team varied, from installing posters of candidates equipped with photos and excellent programs to making pins and using social media. When voting, the committee no longer uses paper media for ballots. Instead, applications were made in computers and laptops for voting facilities. Voters (consisting of students, teachers, and employees) have been given a password to be able to open the 'vote screen'. On the Suara vote screen 'a photo of the candidates is displayed so that voters can click on the desired candidate. In the third stage, the results are published. With the end of the election deadline, the results can be known a few minutes later. This is a series of political events at the school in which political education is contained.

Political education in schools with quite an extended period requires much energy, and drains many thoughts does not seem to be followed up as expected. Based on interviews with the Chairperson of the PK and focus group discussions with PK management participants, data were obtained that not all PK administrators who became the implementing committee understood the function and meaning of the electoral stage as a whole. Moreover, the knowledge and experience of being an implementer will be followed up and developed into a choice of profession in the future.

Likewise, what happens to short-listed and unselected candidates and their successful teams. From interviews conducted separately, it turns out they did not understand the function and meaning of the electoral stage as a whole. After a focus group discussion, the lack of understanding of the function and meaning of this

Please Cite This Articel As : Basuki agus priyana, Construction of Middle School Students (SMA) Against Political Education (Phenomenology Study of State High School 3 Malang Students): Journal of Local Government Issues (LOGOS), https://doi.org/10.22219/LOGOS.Vol2.No2.225-243 
stage also occurs in each candidate's success team. As a result, they are not interested in pursuing a profession related to politics. Though substantively, they have a stock of knowledge as a result of political education that has been undertaken.

The reluctance of students to follow up on the process and results of political education in schools needs to be studied further. In the initial interview of the study of the parents of the Student Council Chairperson and Chairperson PK found two answer groups. First, parents provide full support to their children when involved in various activities nuanced political education at school. This is evidenced by the various facilities and opportunities given by parents to their children. Second, in the question section related to the utilization of political education in schools, the majority of parents do not allow their children

It needs to be reiterated that political education is primarily the activity of rearranging norms, rules and values that have so far existed and efforts to present new values. Like the intelligence process, this activity prepares the process of transferring knowledge, forming individual positive attitudes, and shifting behaviour towards a more dignified order. The building of political education is ideally a construction of cognitive, psychomotor, and attitude aspects. It is just that the phenomenon that arises at this time administrative buildings are often narrowed down into voting activities during elections.

The discussion of the relationship between political education and the state also impacts the discussion of power, decisions, policies, and distribution of power. There is no doubt that political activity will end in the acquisition of power. Furthermore, power will be filled in the activities of decision making, policymaking, and to achieve balance and effectiveness; power distribution will also be carried out. Thus political education constructed by the public will impact on many things, including participation and stability of the country.

Another reason to position political education as an essential thing is because of the emergence of the phenomenon of decreasing numbers of population participation (say: voters) over the past 20 years. Based on data released by the General Election Commission (KPU), during the four elections in the reformation era (in 1999, 2004, 2009, and 2014), the number of people who had the right to vote increased by $17.3 \%-21.7 \%$. However, what is very ironic is precisely the decline in voter turnout. Strangely, the increase occurred in the case of mass rage related to the election results, and the election results lawsuit, the practice of money politics, and the high cost of 'politics'. This symptom is allegedly the failure of political education that is being applied today (Michael and Althoff 1997); (Asshiddiqie 2013).

Starting from the intensive involvement of students in political education activities but the lame follow-up, it needs to be questioned why this happened. That is why the problem of this research is focused on how the actual construction of high school students towards political education. Furthermore, the research aims to describe and understand the construction of high school students in political education. The general use is finding propositions related to the construction of political education.

Please Cite This Articel As : Basuki agus priyana, Construction of Middle School Students (SMA) Against Political Education (Phenomenology Study of State High School 3 Malang Students): Journal of Local Government Issues (LOGOS), https://doi.org/10.22219/LOGOS.Vol2.No2.225-243 


\section{LITERATURE REVIEW}

In order to determine the author's position in this study, some relevant prior studies are presented first. Presented four previous studies that are relevant to this study.

The political moment, especially the Presidential Election, presents the results of the electability survey of candidates. To understand this, adequate statistical literacy is needed by students to be able to read the survey results properly. The teacher becomes an essential factor in providing political education for students as novice voters to have critical literacy in reading statistics. Mathematics education can then collaborate with political education within the school environment

The generation of Indonesian high school children had a relatively low political awareness in viewing the political realities that occurred around them. In order for students to be sensitive to political dynamics, schools need to facilitate the improvement of learning (political education) that can be done through Civics, OSIS activities, extracurricular activities and other activities such as workshops and training to provide political information to students

Students do not fully understand beginner voters in the Election of Regent and Deputy Regent Districts on 15 February 2017, students' knowledge of the electoral techniques and how being a smart voter. That is why the Lembata Regency Regional Election Commission (KPUD) through the District Election Committee (PPK) needs to conduct direct socialization through direct methods to classes like the teaching process. This is very useful because students can directly understand the technicalities of the elections and become critical voters.

Election of OSIS Chairperson (PILKAOS) at SMAN 9 MALANG in 2015 can be an excellent political education for students. Students can be trained to convey aspirations, choose, be responsible, cooperation, honesty and togetherness. This process does take a long time so that it gets complaints from students' parents because sometimes it clashes with other school agendas that are so crowded.

This research, although there are similarities with the eighteen research topics that have been discussed, there are some differences. The main difference lies in the use of theory. In previous studies, the theory used is generally social theory combined with communication theory, mass psychology theory, economic theory, and political theory. However, in this study, two theories are used, namely social construction and learning constructivism. Furthermore, related to background, there are also differences because this research is based on the phenomenon of increasingly enthusiastic students in community and organization, but students tend not to be interested in power and pursue the profession as politicians.

In addition to aspects of the use of theory and background, another difference lies in the determination of informants and research subjects. For informants were Civics teacher and parents of students,

Please Cite This Articel As : Basuki agus priyana, Construction of Middle School Students (SMA) Against Political Education (Phenomenology Study of State High School 3 Malang Students): Journal of Local Government Issues (LOGOS), https://doi.org/10.22219/LOGOS.Vol2.No2.225-243 
while the subjects of the study were the Student Council Chairperson and the PK Chair (Class Representative). This is different from similar studies discussed because they generally use random sampling.

\section{Political education}

Political education is the climax of good general education. This statement stems from a phenomenon that occurred in England in the 1970s when the secondary school curriculum discussed more subjects such as history, language, and geography than social science, governance and politics in a broader context. Civic education at the secondary education level must exist, both for self-interest and the benefit of the public, let alone merely feed the learner to a higher range, namely the university (Crick and Heater 2012).

Another review mentioned that political education is the reconstruction of the values that have existed and built new values. Typically education, this provides a process of transformation of knowledge, the formation of individual attitudes and changes in the intended behaviour. The first aspect, concerns the cognitive dimension, while the second and third aspects are affective and behavioristic (Soeprapto, Susilasti et al. 2015). Thus political education has essential and strategic meaning because it moves citizens (voters) to have adequate political knowledge, as well as awareness of the importance of an ideal political system and intelligent and critical political behaviour.

Political socialization in terms of the method of delivering messages can be divided into political education and political indoctrination. Political education is a dialogical process between the giver and receiver of the message. In contrast, political indoctrination is a one-sided process when the authorities mobilize and manipulate citizens to accept values, norms, and symbols that the ruling party considers ideal and suitable (Surbakti 2010).

Research Theoretical Framework

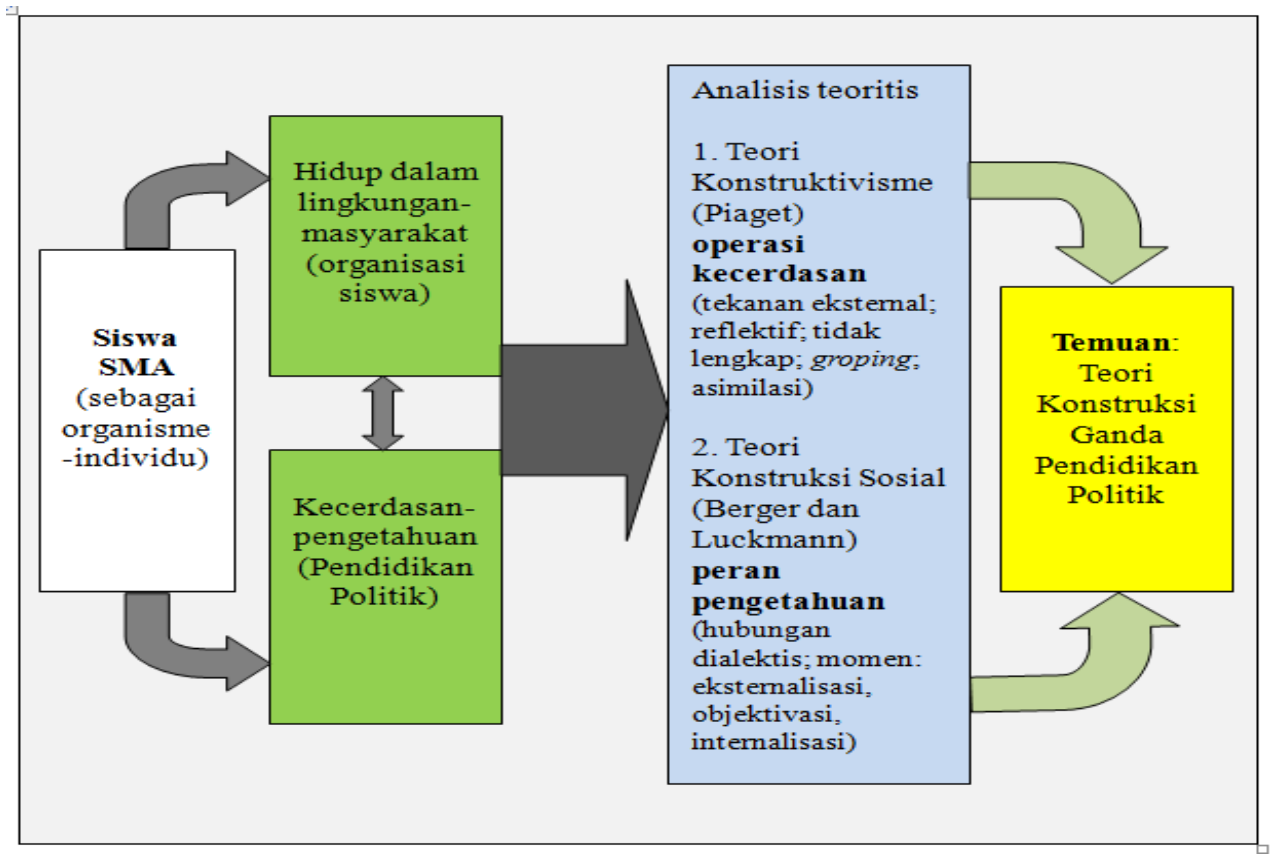

Please Cite This Articel As : Basuki agus priyana, Construction of Middle School Students (SMA) Against Political Education (Phenomenology Study of State High School 3 Malang Students): Journal of Local Government Issues (LOGOS), https://doi.org/10.22219/LOGOS.Vol2.No2.225-243 


\section{METHODS}

This research uses social definition paradigms. This choice is based on the specificity of the problem under study, the research subject, and the chosen research method. Analysis of social action is a central copy of the paradigm of social definition. The main thesis is the 'meaningful action' of the individual. The type of research is qualitative. Of the five types of qualitative research (biographical life history, phenomenology, grounded theory study, ethnography, and case study), this study uses phenomenology studies due to several considerations. First, the type of research problem questions the meaning of an event or action for someone. Second, there is something you want to study with the guiding words "how" and "why". Third, there are symptoms or things that appear and focus on individual consciousness called intentionality. Fourth, data collection techniques in the form of in-depth interviews and participatory observation (Creswell 2010).

This research was conducted at SMA Negeri 3 Malang. There are several reasons attached to it. First, researchers work in this place so that observations and interviews are more freely carried out. Secondly, out of ten state high schools in Malang, the number of students accepted at Malang State High School 3 is the least, amounting to $250-290$ people, so the competition is very tight. The third reason, the best graduates from almost all junior high schools in Malang and surrounding areas always compete to be accepted in SMA Negeri 3 Malang.

The next reason is related to regulations imposed by the Ministry of Education and Culture. Since the end of the International Standard School Pilot Project (RSBI) in 2014, SMA Negeri 3 Malang has become a pilot project for Model Schools and Referral Schools. Model schools mean schools with proper management and results used as a pattern or role model, while referral schools mean schools that are worth referring to and are emulated because of their excellence in delivering graduates to be accepted at state universities. Other considerations are achievement factors and superior programs. The Ministry of Education and Culture in 2016 ranked Malang Public High School 3 in eighth place. Another achievement is the accreditation "A" with a value of 93, which was achieved in 2016.

The informants of this study were Civics teacher (Anisah Hariati, S.Pd.), parents of students (Neti and Virda), and student council coaches. The research subjects totalled ten people as OSIS Chairperson and PK Head of Malang 3 Public High School in 2013-2017. Retrieval of data against the Chairperson of the student council and the head of PK is done when his term of office has passed, or he is still in office.

Data collected through observation, interviews, and documentation. Next, the data were analyzed using the Creswell model with the following steps.

1. Process and prepare data for analysis.

Please Cite This Articel As : Basuki agus priyana, Construction of Middle School Students (SMA) Against Political Education (Phenomenology Study of State High School 3 Malang Students): Journal of Local Government Issues (LOGOS), https://doi.org/10.22219/LOGOS.Vol2.No2.225-243 
2. Read the entire data.

3. Analyze more deeply by coding data.

4. Implement the coding process to describe the settings, people, categories, and themes to be analyzed.

5. Demonstrate how these descriptions and themes will be restated in the qualitative report.

6. Interpreting or interpreting data, for example, by asking the question "What is the meaning that can be drawn from all this?"

\section{RESULTS AND DISCUSSION}

There are three variations of answers related to the concept of political education. The first variation mentions that political education is a guide for residents to elect governors and deputy governors as well as guidelines for choosing mayors and deputies. Directions and guidance are given in the hope that the people (voters) will not become abstentions or deliberately do not use their right to vote.

The second variation related to the concept of political education is education so that people participate in the selection of members of the DPR, the president and vice president or state authorities. This concept implies that election refers to a person to lead a group of people or individuals chosen to represent. Once again, the research subjects did not mention the election of DPD members. In this variation of the word, education is not spelt out but found in the form of details or explanatory form of the words participating and member selection.

The concept of political education in the third variation of answers is guidance and teaching to the audience, including high school students in the form of lectures, simulations, and practices, so that they are skilled in choosing leaders. In a narrower scope, that is school, is teaching students to know so that they can choose student council and extracurricular officials who can be trusted, smart, and capable. The hope is to brighten student council activities and advance extracurricular activities. If the student council and extracurricular activities advance, the school will become advanced too.

The diversity of understanding of political events has an impact on the concept of political education. When the concept of political education is associated with the role of the individual as the Chairperson of the Student Council or PK, several variations are found. First, to formulate the concept of political education, individuals still refer to the most significant political events surrounding them. This is evident in the explanation that political education is a guide to choosing governors and mayors. Second, the concept of political education is formulated by the individual by referring to his role as Chair of the Student Council or PK. The role is interpreted as the task of organizational leaders in the school environment to plan, invite others, decide on steps, divide tasks, report, and account for. Another explanation is the problem of power

Please Cite This Articel As : Basuki agus priyana, Construction of Middle School Students (SMA) Against Political Education (Phenomenology Study of State High School 3 Malang Students): Journal of Local Government Issues (LOGOS), https://doi.org/10.22219/LOGOS.Vol2.No2.225-243 
leaders ranging from planning power, the process of gaining power, sharing power, evaluating power, and reporting it.

Third, individuals formulate the concept of a political education by integrating their roles as OSIS Chairperson or PK and surrounding events. The combination of roles and surrounding events can be explored from the statement that political education is socialization to friends, teachers, and employees related to shared goals, such as electing leaders, mandating power to legislators, and prosecuting corruptors.

Based on the data of the first group, the concept of political education is determined by the events surrounding the individual and the role that the individual has.

The second data group consists of the implementation of political education in student activities. The intended implementation is motivation to lead, ownership of a successful team, to the distribution of power and their consideration. Found the concept of political education in line with the motivation to lead, successful team ownership, and power-sharing. The second variant found the concept of political education in line with the motivation to lead and the ownership of a successful team but not in line with the distribution of power. The third variant of the concept of political education is in line with the motivation to lead but not in line with the ownership of the victorious team and the division of power. The fourth variant of the concept of political education is not in line with the motivation to lead, ownership of a successful team, or the distribution of power.

Of the ten research subjects, motivation to be the Chair of the Student Council and the Chair of the PK is very diverse. Found research subjects who do not have the motivation to lead, motivation comes from the environment (parents, student council / PK board, and peers), self-motivation, and motivation to lead because they are forced. Furthermore, it was found that the reason for being the Student Council President or PK Chair was due to a sense of kinship, obsession with benefits, diversion from gaming addictions, getting out of the comfort zone, desire for power, self-actualization, antisocial nature therapy, and dialectical models between challenges and opportunities.

Based on the second data group, the implementation of political education in student activities has several variations. This is determined by the motivation to lead, the ownership of the victorious team, and the power-sharing mechanism.

The third data group contains a discussion of the objects of political education, subjects related to political education, and subjects related to the election of OSIS / PK Chairperson as part of political education. Before digging up data in the form of objects of political education, the terminology used about political education is used. This step was not responded well by research subjects because of the unknown

Please Cite This Articel As : Basuki agus priyana, Construction of Middle School Students (SMA) Against Political Education (Phenomenology Study of State High School 3 Malang Students): Journal of Local Government Issues (LOGOS), https://doi.org/10.22219/LOGOS.Vol2.No2.225-243 
'scientific discipline'. As a form of anticipation, the designation of the object, content, or content of political education is used. This step was relatively successful until several data groups were obtained.

Almost all research subjects did not specifically mention the content of political education. All answers tend to be very general, such as the content of political education being able to bring people closer to the government, about how to manage the country, the ability to communicate, strengthen a sense of responsibility, skills to persuade others, political ethics, how to achieve goals, how to choose and lead, know differences executive and legislative branches, and knowledge of one's relationships with others.

The second part of the object of study of political education in subjects related to the election of OSIS / PK Chairperson as part of political education. Found a group of subjects that are accepted by students in learning in schools and science groups outside the subjects in school. The first group is Civics Education, language, history, mathematics, sociology, economics, information technology, religious education, and arts. The second group is psychology, political science, political science, and the science of social change.

The exciting part related to this subject is the explanation of the research subject to the stages in the general election. The research subjects were found to explain that Civics and language subjects play an essential role in the preparatory stage of voting. The reason is that in the Civics lesson, there is material about the transfer of power, the procedure for electing and being elected, the management of the state, and the function of representation in a democracy. Still, in the preparation stage, it is said that language has a vital role because in it there is an activity of communicating ideas and persuading others to agree with these ideas.

At the general election stage, strictly related subjects are mathematics and information technology. I have called mathematics because of the predominance of the activity of counting votes, percentage, vote ranking, and so on. Furthermore, information technology is said to play a role at this stage because the reporting mechanism is tiered, starting from the lowest to the very top. Also, the publication of election results as the peak of the election involves the information technology network.

The first object of political education is the rules, its contents in the form of the Articles of Association (Bylaws) in the scope of OSIS / PK activities. Furthermore, in the form of laws with a broader scope because it accommodates national and state activities. Regulation in the form of this law can be focused on discussing election issues, the system of representation, the role of the executive and legislative branches, or the rule of the state in general. In addition to rules, the process of the formation of rules can also be developed into an object of political education.

Knowledge, skills and attitudes are the next objects of political education. The realm of knowledge such as procedures for exercising rights, procedures for choosing and being elected, procedures for sharing

Please Cite This Articel As : Basuki agus priyana, Construction of Middle School Students (SMA) Against Political Education (Phenomenology Study of State High School 3 Malang Students): Journal of Local Government Issues (LOGOS), https://doi.org/10.22219/LOGOS.Vol2.No2.225-243 
power when leading, and procedures for taking responsibility for power. The skill dimension is the ability to communicate, persuade, work in teams, and the ability to find problems and offer solutions. The realm of attitude in the form of obedience, responsibility, innovation, and most importantly is ethical.

The next study is subjects related to political education. Found several variations of answers in the form of groups of subjects indoctrination, mindset development, and improvement of skills - indoctrination subject groups such as religious education, Civics, history and psychology. Next, the mindset development group, for example, social science and the science of community development. Finally, subjects to improve skills, for example, language, economics, mathematics, and ICT.

All research subjects named Civics Education first. The reason is, some of these study chapters discuss political education specifically, ranging from the rights of citizens to the rights of state and state administrators themselves. Other subjects called randomized research subjects are language, history, economics, religion, psychology, sociology, art, and Information and Communication Technology (ICT). This second group of subjects is often referred to as leader support lessons because it is based on knowledge, skills and attitudes.

The next data exposure is subjects related to the election of OSIS / PK Chairperson as part of political education. This study is similar to the previous section but focuses on the view that there are certain subjects related to the selection of OSIS / PK Chairperson as part of political education. There are three groups of lessons, starting at the stage before the election, at the time of the election, and after the election. The stage before the selection of the essential subjects Civics, followed by history, language, and economics. At the time of the election, Civics subjects are still needed in a capacity as a basis for regulation, mathematics and ICT as supporters. After the selection, language and ICTs are needed to communicate and account for the results of the election.

Discussion of subjects related to the election of OSIS / PK Chairperson as part of political education is not much different from the previous discussion. The research subjects provided a reason or supplementary explanation in the form of the contribution of the lesson. Civics Education is said to be related to the election of OSIS / PK Chairperson because it provides leadership provisions from the preparation stage to the transfer of power. Likewise, for language, economics, sociology, and history. This is different from ICT lessons because it is limited to the selection and publication of election results.

Conceptualization of third group data that the objects of political education are interpreted as material, content, or content needed in political education. The stages of the political process determine its diversity and its use pragmatically.

Please Cite This Articel As : Basuki agus priyana, Construction of Middle School Students (SMA) Against Political Education (Phenomenology Study of State High School 3 Malang Students): Journal of Local Government Issues (LOGOS), https://doi.org/10.22219/LOGOS.Vol2.No2.225-243 
The final data group discusses the benefits of political education in subject activities as OSIS / PK Chairperson. The discussion of the benefits of political education is guided by a central question and three development questions. Development questions arise due to the repetition of answers to research subjects. The main questions lead to the benefits of political education, while the development questions relate to the attitude of responsibility, ownership of power, and the ability to solve problems when the subject becomes the Chairperson of the student council / PK.

When talking about the benefits of political education, all research subjects stated that it was beneficial. The statement refers to theoretical and pragmatic matters. Theoretical matters are found in the answers of research subjects who say that political education is the subject of some sciences because the nature of politics is the science of survival. Besides that, political education is useful to shape one's mindset in facing challenges.

In another section, it is found the pattern of answers to research subjects that lead to the four benefits of political education. First, political education provides benefits in understanding various interests. Second, it is useful in the context of government and the private sphere, in this case, the business world. Third, it provides benefits in the form of provision of communication skills and understanding of others. Finally, it provides benefits in the form of political intelligence so that students become intelligent, not easily cheated or manipulated.

The first question of developing the benefits of political education is "When you become the head of the student council or PK, do you feel you have more responsibility?" All research subjects stated that their responsibilities had become more magnificent. The explanation given is very diverse, but the reasons can be grouped into three, namely the reasons with the realm of knowledge, skills, and attitudes.

The second question of developing the benefits of political education is, "When you were the head of the student council or PK, did you feel that you had more power?" Three groups of answers were found to benefit the benefits of political education about power. The first group confidently felt they had more power. The second group does not feel they have more power, while the third group seems doubtful of more power.

The explanation given related to ownership of power can be grouped five. First, higher power serves as a solution to the problem. Second, more power is useful for achieving a goal. Third, higher power plays a role in bringing about change for the better. Fourth, higher power means limiting because of the existence of binding rules, for example, bylaws and bylaws. Finally, more power is temporary because nature is simply a transfer of the role of being led to leading.

The last part of the discussion of the benefits of political education is the ability to solve problems. Two groups of answers were found between those stating agreement that when they became chairman of the

Please Cite This Articel As : Basuki agus priyana, Construction of Middle School Students (SMA) Against Political Education (Phenomenology Study of State High School 3 Malang Students): Journal of Local Government Issues (LOGOS), https://doi.org/10.22219/LOGOS.Vol2.No2.225-243 
Student Council or PK could solve problems and those who stated no. Which states no, explains that during the office, it was there when learning to solve problems. This answer is an agreement, but with a different problem-solving point of view, that is, seeing it from the process.

Research subjects who stated consent provided varied explanations. Some say the ability to solve problems is marked by a sense of calm, reviewing the problem from several sides, and positioning as an intermediary in resolving conflicts. Other explanations that are complementary that the ability to solve problems do need to be trained, the level of problems, the frequency of problems coming determine the ability to solve problems, and the ability to solve more significant problems is done efficiently.

The fourth conceptualization of data groups, namely the theoretical and pragmatic benefits of political education, is determined by the role of individuals in social interaction.

\section{Constructivism}

The subject of Piaget's theory is the operation of intelligence. Also, Piaget discusses two components related to intelligence operations, namely organisms and the environment. In the triangle frame of mind, intelligence is placed at its peak, while the environment and organisms are at two corners of the base. All three have the potential to change positions, depending on the point of view and focus of the discussion (Piaget 1952).

First, all research data will be discussed with the intelligence operation of Jean Piaget's constructivist theory. In its development, it turned out that the data from the 20 questions, narrowed to four groups. The four data groups are the concept of political education, implementation of political education, objects of political education, and the benefits of political education (Piaget 1952).

Please Cite This Articel As : Basuki agus priyana, Construction of Middle School Students (SMA) Against Political Education (Phenomenology Study of State High School 3 Malang Students): Journal of Local Government Issues (LOGOS), https://doi.org/10.22219/LOGOS.Vol2.No2.225-243 


\section{High School Student Intelligence Operation Chart Against Political Education}

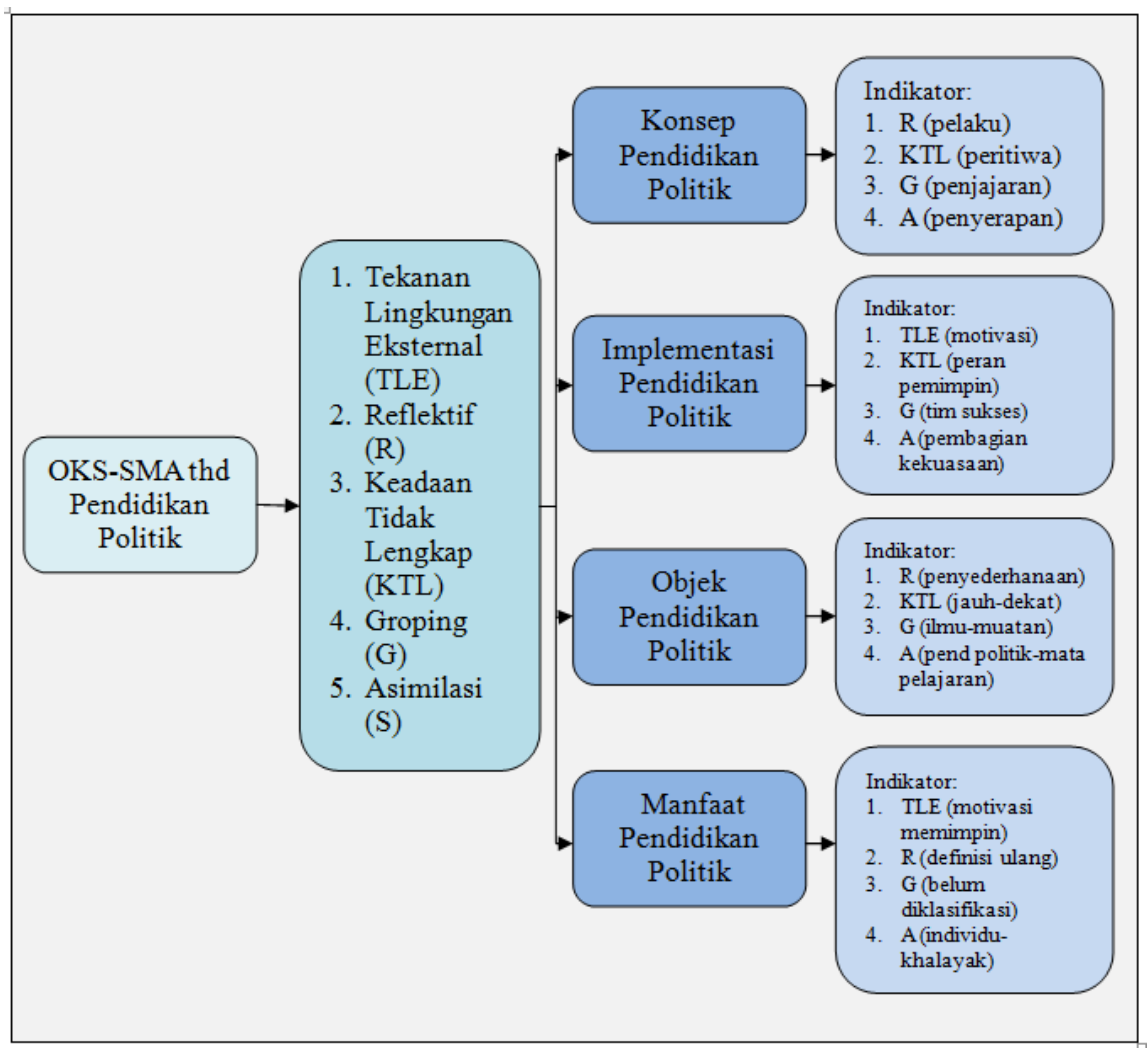

The second theory used to discuss the results of research is the theory of social construction Peter $\mathrm{L}$ Berger and Thomas Luckmann. About this theory, this study positions high school students as individuals. These individuals live in a community environment, in the form of student organizations, both OSIS and PK. Furthermore, individuals who live in the OSIS and PK environment construct political education (Berger, Parera et al. 1990).

In Berger and Luckmann's social construction theory, there are moments of externalization, objectivation, internalization, socialization, resocialization, and stock of knowledge. Simply externalization is interpreted as physical and mental outpouring, objectivation is interpreted as the result of physical and mental outpouring, internalization as an effort to re-absorb, socialization as an effort to convey the results of absorption, resocialization is interpreted as an effort to deliver again, and stock of knowledge is interpreted as a stock of knowledge that settles itself in self (Berger, Parera et al. 1990).

Please Cite This Articel As : Basuki agus priyana, Construction of Middle School Students (SMA) Against Political Education (Phenomenology Study of State High School 3 Malang Students): Journal of Local Government Issues (LOGOS), https://doi.org/10.22219/LOGOS.Vol2.No2.225-243 


\section{High School Student Construction Process Chart Against Political Education}

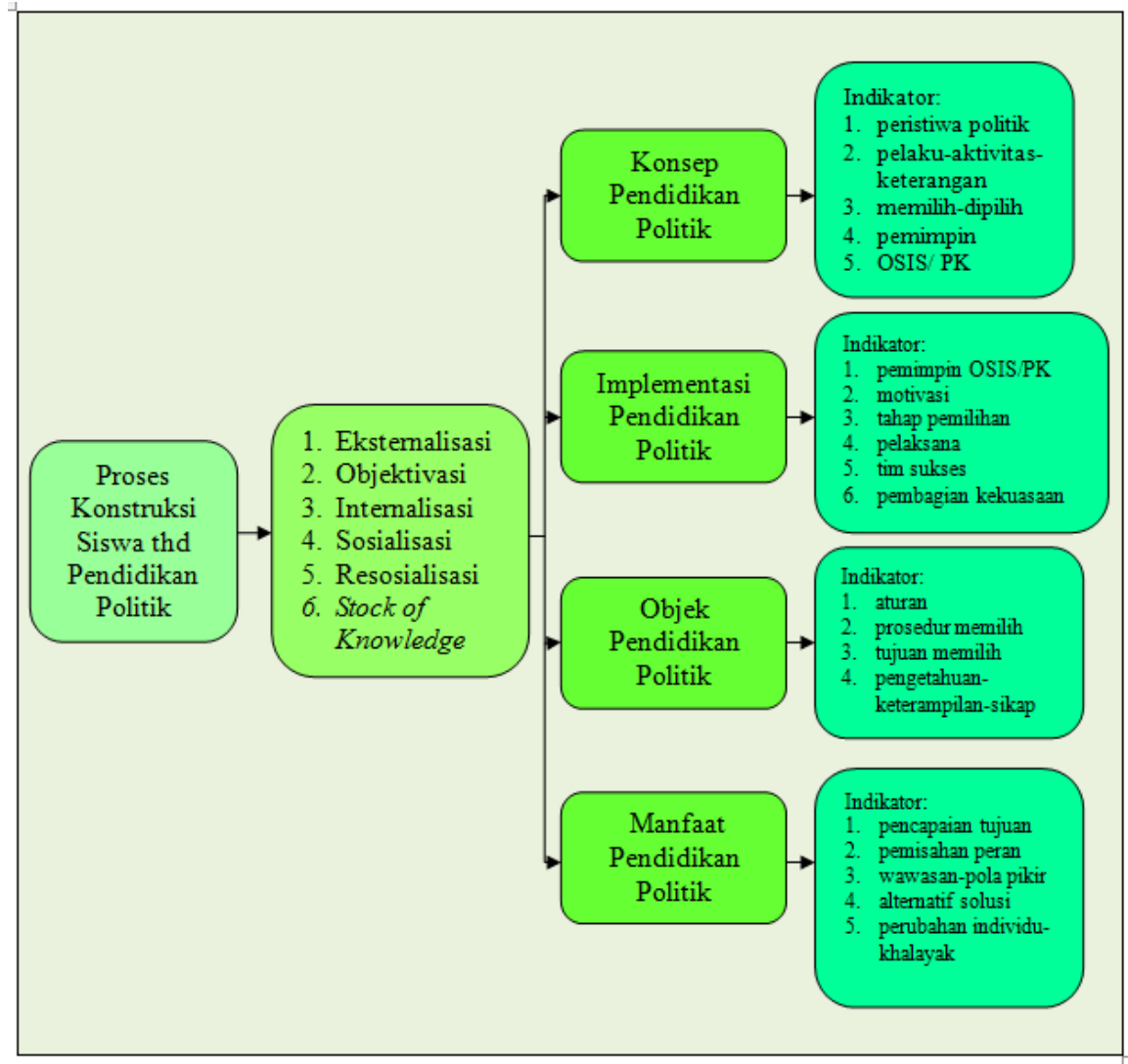

This high school student construction research on political education has resulted in the strengthening of Jean Piaget's constructivist theory, especially regarding intelligence operations in the form of external environmental pressures, reflections, rough conditions, groping, and assimilation. However, not every discussion brings up these five intelligence operations. For Berger and Luckman's social construction theory, high school student construction research on political education modifies the theory, especially in the position of three moments of externalization, objectivation, and internalization in the 'input' and the construction process. As for socialization, resocialization, and stock of knowledge in the 'output' position of construction.

\section{Tip for High School Student Political Education}

Typification begins with the activity of acceptance, understanding and appreciation of norms. Furthermore, accepted norms are implemented and repeated until they become a habit. Repetition and use of these norms become types or characteristics. Following are some tips for high school students regarding political education.

1. Political education as an activity of increasing knowledge and skills in terms of choosing or leading by involving a group of people and the environment.

Please Cite This Articel As : Basuki agus priyana, Construction of Middle School Students (SMA) Against Political 
2. Implement political education in the form of leadership motivation, the process of becoming a leader, and the distribution of power based on a redefinition of the concept of political education.

3. The object of political education is knowledge such as lessons in school and skills such as activities in OSIS / PK.

4. The benefits of political education manifest in the attitude of responsibility, ownership of power, and the ability to solve problems.

\section{Proposition for Multiple Construction Theories}

1. The concept of political education as a redefinition follows the operations of the intelligence of reflection, rough conditions, groping, and assimilation and requires a reserve of knowledge to undergo externalization, objectivation, internalization, socialization, and resocialization.

2. The implementation of political education is based on a redefinition by following the intelligence operations of external environmental pressures, rough conditions, groping, and assimilation as well requires a backup of knowledge to undergo externalization, objectivation, internalization, socialization, and resocialization.

3. The component of redefinition fills the object of a political education by following the operations of intelligence reflection, rough conditions, groping, and assimilation and requires a reserve of knowledge to undergo externalization, objectivation, internalization, socialization, and resocialization.

4. The benefits of political education as an embodiment of redefinition by following the intelligence operations of external environmental pressures, reflection, groping, and assimilation so that they require a reserve of knowledge for externalization, objectivation, internalization, socialization, and resocialization.

\section{Multiple Construction Theories}

1. Principle: the essence of political education is the redefinition of concepts to be applied to implementations, objects, and benefits by involving intelligence operations and construction processes.

2. Key assumptions: double construction to produce a redefinition is a combination of intelligence operations in the form of external environmental pressures, reflections, rough conditions, groping, and assimilation as well as the construction process that requires a reserve of knowledge to undergo externalization, objectivation, internalization, socialization, and resocialization.

Please Cite This Articel As : Basuki agus priyana, Construction of Middle School Students (SMA) Against Political Education (Phenomenology Study of State High School 3 Malang Students): Journal of Local Government Issues (LOGOS), https://doi.org/10.22219/LOGOS.Vol2.No2.225-243 


\section{Dual Construction Chart for Political Education}

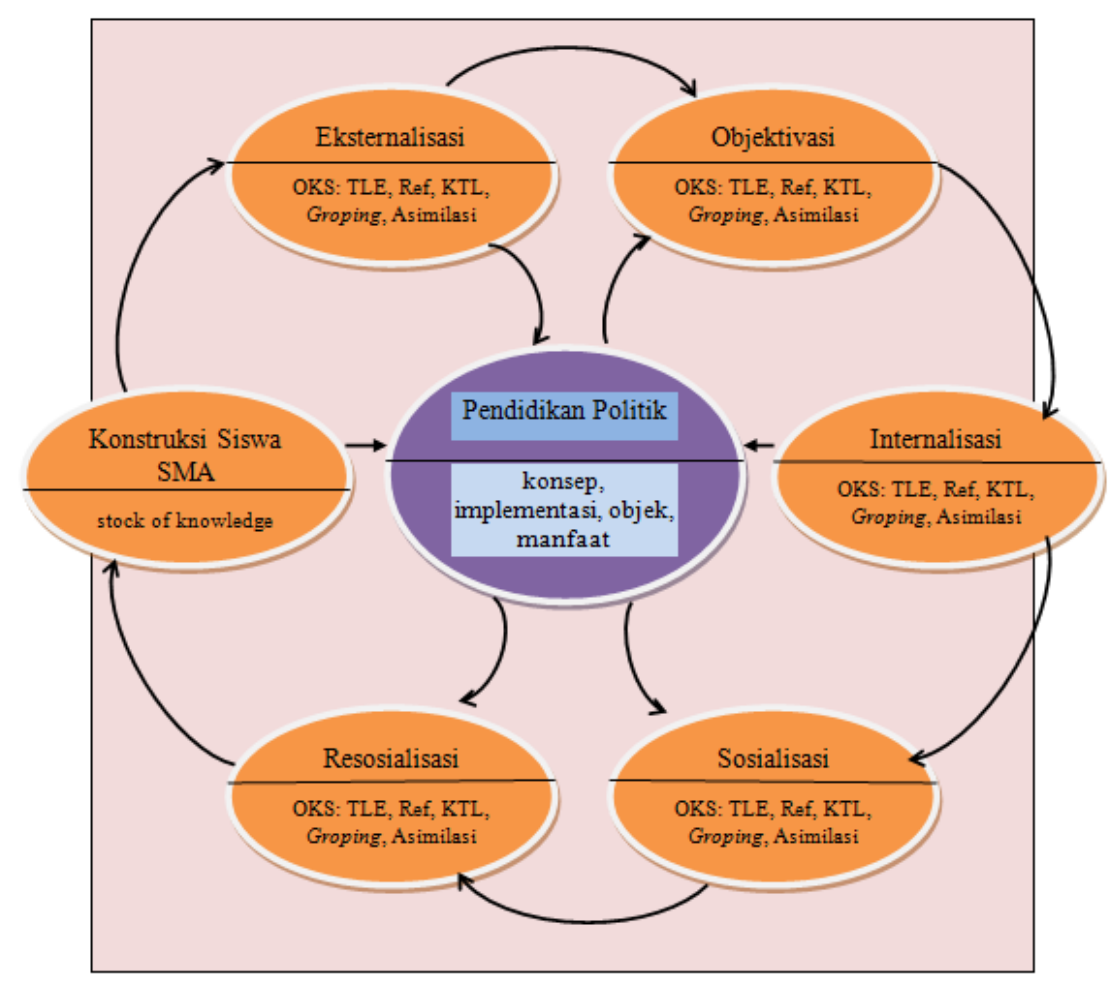

\section{CONCLUSION}

The construction of high school students on political education in the form of concepts, implementation, objects, and benefits, follows the five operations of Piaget's theory of constructivism such as external, reflective, incomplete circumstances, groping, and assimilation, but with different dominance and sequence. Construction of high school students on political education in the form of concepts, implementation, objects, and benefits, applying dialectics between individuals (high school students), society (student organizations), and knowledge (political education) that takes place in the order of moments of externalization, objectivation, and internalization, while 'output' follows the moment of socialization and resocialization to the stock of knowledge.

The findings of this study are called the dual construction theory of political education. It is called a double construction because high school students' construction of political education follows the intelligence operations of constructivism theories such as external environmental pressures, reflections, incomplete conditions, groping, and assimilation, as well as applying dialectics of social construction theory with moments of externalization, objectivation, internalization, socialization, resocialization, and stock knowledge.

The results of this study have the potential to be further developed. Apart from all theoretical, methodological and analytical deficiencies, the following suggestions can be submitted. First, the executive 
(Malang City Government), the legislature (DPRD members), the Regional Election Commission (KPUD), and the Election Supervisory Body (Bawaslu) should utilize the findings of this research by designing programs to enrich political knowledge and skills, for example, to gather aspirations from the public. High school students as young voters. Second, it is time for parents, schools, and alumni to use the findings of this study to develop students' political attitudes, knowledge and political skills. Third, based on the research findings, it is expected that political parties will no longer take the role of users of political persons, but instead will be forming or producing ethical and quality political persons.

\section{REFERENCE}

Asshiddiqie, J. (2013). Menegakkan etika penyelenggara pemilu, PT RajaGrafindo Persada.

Berger, P. L., et al. (1990). Tafsir sosial atas kenyataan: Risalah tentang sosiologi pengetahuan, LP3ES.

Creswell, J. W. (2010). "Research design pendekatan kualitatif, kuantitatif, dan mixed." Yogyakarta: Pustaka Pelajar.

Crick, B. and D. Heater (2012). Essays on political education, Routledge.

Michael, R. and P. Althoff (1997). Pengantar Sosiologi Politik, Raja Grafindo. Persada. Jakarta.

Piaget, J. (1952). The Origins of Intelligence in Children New York: Int, Univ. Press.

Soeprapto, A., et al. (2015). "Komunikasi Dalam Proses Pendidikan Politik Pemilih Pemula Dalam Pemilihan Umum 2014 di DIY." Jurnal Ilmu Komunikasi 12(1).

Surbakti, R. (2010). "Memahami Ilmu Politik, Jakarta." PT Gramedia Widiasarana Indonesia.

DPP Partai Nasdem. tanpa tahun. Anggaran Dasar dan Anggaran Rumah Tangga Partai Nasdem. Naskah tidak diterbitkan.

DPP Partai Kebangkitan Bangsa. (2014). Anggaran Dasar dan Anggaran Rumah Tangga Partai Kebangkitan Bangsa. Jakarta: Sekjen DPP PKB.

DPP Partai Keadilan Sejahtera. (2013). Anggaran Dasar dan Anggaran Rumah Tangga Partai Keadilan Sejahtera. Naskah tidak diterbitkan.

DPP Partai Demokrasi Indonesia Perjuangan. tanpa tahun. Anggaran Dasar dan Anggaran Rumah Tangga Partai Demokrasi Indonesia Perjuangan. Naskah tidak diterbitkan.

DPP Partai Golkar. (2004). Anggaran Dasar dan Anggaran Rumah Tangga Partai Golongan Karya. Naskah tidak diterbitkan.

DPP Partai Gerakan Indonesia Raya. (2012). Anggaran Dasar dan Anggaran Rumah Tangga Partai Gerakan Indonesia Raya. Naskah tidak diterbitkan.

DPP Partai Demokrat. tanpa tahun. Anggaran Dasar dan Anggaran Rumah Tangga Partai Demokrat.

Please Cite This Articel As : Basuki agus priyana, Construction of Middle School Students (SMA) Against Political Education (Phenomenology Study of State High School 3 Malang Students): Journal of Local Government Issues (LOGOS), https://doi.org/10.22219/LOGOS.Vol2.No2.225-243 
Naskah tidak diterbitkan.

DPP Partai Amanat Nasional. tanpa tahun. Anggaran Dasar dan Anggaran Rumah Tangga Partai Amanat Nasional. Naskah tidak diterbitkan.

DPP Partai Persatuan Pembangunan. (2014). Anggaran Dasar dan Anggaran Rumah Tangga Partai Persatuan Pembangunan. Naskah tidak diterbitkan.

DPP Partai Hanura. (2010). Anggaran Dasar dan Anggaran Rumah Tangga Partai Hati Nurani Rakyat. Naskah tidak diterbitkan. 